\title{
The Effect of Internal Controls on the Financial Performance of Commercial Banks in Kenya
}

\author{
Mr. Asiligwa, G. Rennox \\ (Department of Finance and Accounting, University of Nairobi, Kenya)
}

\begin{abstract}
The objective of the research was to establish the Effect of Internal Controls on Financial Performance of Commercial Banks in Kenya. Internal Controls were measured using the five elements of internal control as stipulated by the Committee of Sponsoring organizations of Treadway Commission framework of internal controls while Financial Performance was measured using the historical average of Return on Equity. A descriptive research design was adopted due to its ability to describe the relationship between elements of Internal Controls and Financial Performance. The study used the 43 commercial banks in Kenya. Primary data was collected using a structured questionnaire. Descriptive statistics obtained from data analysis were presented using frequency tables, while inferential data findings were presented using correlation and regression tables. The study findings revealed that the banking sector enjoys a strong financial performance partly because of implementing and maintaining effective internal controls. The existence of effective internal control is attributed to the highly regulated and structured environment in the banking sector. The study recommends banks should effectively implement and maintain internal controls due to the nature of the riskiness of the banking sector and its impact on financial performance.
\end{abstract}

Key words: Commercial Banks, COSO Framework, Financial Performance, Internal Controls, Kenya.

\subsection{Background information}

\section{Introduction}

Internal control is important to all business organizations and more so the banking sector whose business environment is prone to risks that must be mitigated for performance and profitability. Commercial banks in Kenya dominate the Financial Sector and therefore have a tremendous impact on the economic growth and financial stability of this Country. Flamini et al. (2009) indicated that studies carried out in the last two decades show commercial banks in the Sub-Sahara Africa are more profitable with an average return on Asset of $2 \%$. In the spirit of finding out the factors contributing to such performance, this research established that effective Internal Controls positively affects Financial Performance of the Banking sector in Kenya. Internal controls are the basic organizational elements that help management effectively deliver services to stakeholders; helps ensure reliability of financial statements and compliance with the laws and regulations (COSO, 1992/2004). Organizations with no or weak internal controls run the risk of failure. This fact is supported by the findings of the Treadway Commission Report of 1987 in USA which confirmed that the absence of, or weak internal controls is the primary cause of many cases of fraudulent company financial reporting. The SarbanesOxley(SOX) Act of 2002 was introduced in response to well-publicized accounting scandals of the $21^{\text {st }}$ century that were witnessed at Enron and WorldCom and required all public companies to disclose internal controls over financial reporting. Section 404 of SOX requires management of public companies to issue an internal control report in which they take responsibility for maintaining adequate internal controls, and make assertions concerning their effectiveness.

Kenya has a vibrant banking sector that is relatively stable and well regulated. It consists of the Central Bank of Kenya (CBK) that regulates the banking sector. There were 43 registered commercial banks as at $31^{\text {st }}$ December, 2014, out of which two were under statutory management by the time of the research. These banks were classified as Local/Foreign and Public / Private Banks. There were 3 publicly owned banks, 27 locally owned banks (26 commercial banks and 1 Microfinance Corporation (MFC)) and 14 foreign owned commercial banks (this translates to more than 50\% foreign ownership). These banks are further classified into three main peer groups basing on their market share index. Large banks peer group consisted of banks with a market share index greater than 5\% each. There were 6 banks in this peer. The Medium peer group had 16 banks with a market share index of between $1 \%$ and $5 \%$ each. Lastly the small peer group had 21 banks with a marker share index less than $1 \%$ each. The Large peer group had a total market share index of $49.88 \%$, the Medium peer group with a total market share index of $41.71 \%$ and the small peer group with a total market share index of $8.41 \%$.

The Banking sector in Kenya has continued to register increased profitability, mainly attributed to the Structural Adjustment Programmes(SAP), such as; regulatory initiative on transparency by initiation of Kenya Banks' Reference Rate(KBRR), continued automation, ongoing infrastructure investment by the government, 
higher demand for credit resulting from increased regulated mobilization by the banks in unsecured segments of the market and government's continued growth oriented macroeconomic policies. The total Asset base rose by $18.5 \%$ to stand at 3.2 trillion and customer deposits increased by $18.65 \%$ to stand at 2.29 trillion as at $31^{\text {st }}$ December, 2014.

The internal control system in the banking sector is guided by the framework in banking organizations issued by the Basel Committee (1998) on Banking Supervision. The Basel Committee (1998) stipulated that a system of effective internal controls is a critical component of bank management and a foundation for the safe and sound operation of banking organizations.

\subsection{Research problem}

According to Mawanda (2008), designing and implementation of proper internal controls will always lead to improved financial performance. Weak internal control systems have been known to be perfect fertile ground for perpetration of fraud and scandals. Such was the case for financial scandals of this decade witnessed at Enron and WorldCom. The response to this scandals has resulted in bringing into the law the "Public Company Accounting Reform and Investor Protecting Act" commonly known as the "Sarbanes-Oxley Act (SOX Act)". The SOX Act stipulates clearly that the management should take full responsibility for internal control system over financial reporting within the company and provide assessment of its effectiveness. Mawanda (2008) postulates that the Board of directors ought to supervise the management of an entity, but it has always turned out that the Board merely implements recommendations made by the management committee of an entity. This in fact is possible due to information asymmetry existing between the managers and the Board of Directors.

The Agency theory advanced by Jensen \& Meckling (1976) stipulates that the principals and the agents use contracting to maximize their wealth. However, the agents may face a dilemma of acting against the interest of their principals in an effort to maximize their own wealth. Internal control should be used as a safety net to address this agency problem (Jensen \& Payne, 2003). In the same light, studies have shown that Internal Controls reduce agency costs (Abedel-Khalik, 1993) and this has a positive effect on the financial performance of a business. However, they have not been given the prominence they deserve other than as a regulatory and social accountability requirement.

Internationally, Ejoh and Ejom (2014) studied the relationship of internal control activities and financial performance on tertiary institutions in Nigeria, Ayagre, et al. (2014) researched the effectiveness of internal controls on banks in Ghana and only interrogated two components of internal control; control environment and monitoring. Boyyoud and Sayyad (2015) studied the impact of internal controls and risk management on banks in Palestine. Scholars such as Islam, et al. (2014) used the CAMEL model to proxy financial performance in banks.

Locally empirical studies carried out by Magara (2013) studied the effects of internal controls on savings and credit cooperative societies(SACCOs) in Kenya; Kamau (2014) studied the effect of financial performance of manufacturing firms in Kenya; Nyakundi, et al. (2014) researched on the effect of internal controls on small and medium enterprises (SMEs) in Kisumu. On profitability: Onuonga (2014) researched on the bank specific factors using bank size, capital strength, ownership and operations expenses; Ongore and Kusa (2013) used the Capital adequacy, Asset quality, Management efficiency, Earnings ability and Liquidity(CAMEL) ratios to proxy bank specific factors and Macroeconomic indicators based on growth domestic product(GDP), growth rate and inflation; Olweny \& Shipho (2011) used bank specific factors proxied as CAMEL ratios and market concentration and foreign ownership.

From the studies, it is strongly evident that none of these researches addressed the effect of internal controls on the financial performance of commercial banks. In addition to this there are not as many studies carried out to stipulate the contributions of internal controls on financial performance despite many studies undertaken on financial performance in the banking sector. Therefore, very little evidence does exist on the effect of internal controls in the banking sector. To emphasize this further, Onuonga (2014) stipulated that the impact of determinants of bank's performance is inconclusive. This study aims to feel this gap by answering the question "what is the Effect of Internal Controls on Financial Performance of Commercial Banks in Kenya?"

As a result, this paper aims at determining the effect of internal controls on the financial performance of commercial banks in Kenya. This study is important since internal controls affect financial performance by mitigating risk, minimizing fraud and errors that could result in material misstatements, promoting efficiency and effectiveness of activities performed, giving reliable, complete and timely information for decision making and ensuring compliance to laws and regulations in the banking sector. The study will help various groups such as senior bank management and board of directors who are mandated with governance of the institutions by emphasizing on the importance of designing an effective internal control system that would assist them achieve their corporate goals. In addition, this study will be useful to shareholders by providing reasonable assurance that the objectives of the business they invest in shall be achieved and that their investment is safe from fraud. 
This study further, provides recommendations to government and the regulatory bodies on how best to address existing and foreseen problems in the banking sector.

\subsection{Theoretical framework}

\section{Literature Review}

This research is on the theories that suggest the factors that link bank performance with internal controls. They include the Efficiency Structure Theory, Agency Theory and Institutional Theory.

\subsubsection{Efficient structure theory}

The theory originated from the works of Demsetz $(1973,1974)$. Higher profits are the results of firm's specific advantages, such as greater efficiency, instead of higher market concentration (Peltzman, 1977). This theory suggests that banks that earn high profits are more efficient than others are. This results in low operational costs leading to profitability. It also seeks to explain the relationship between bank size and profitability. It is best explained through two hypotheses: X-Efficiency (ESX) hypothesis and the hypothesis of scale of Efficiency (ESS). ESX hypothesis assumes that most efficient firms can earn higher profits due to production technology and superior management that allows them to reduce their costs (Berger, 1995). This implies that high level of x-efficiency gives banks opportunity to earn higher profits, be more efficient and therefore maximize on financial performance. The ESS hypothesis stipulates that firms that produce at scales more efficiently compared to other competitors have lower unit costs and higher profits. Several scholars have done research to back up these hypotheses and found out that these theories together with MP had a positive effect on bank performance. (Park and Weber (2006), Olweny and Sipho (2011), Mensi and Zouari(2011), Chortareas et al.(2009)). Olweny and Sipho (2011) argue that MP is a function of external market factors and ES is a function of internal factors. This study relates to the X-Efficiency (ESX) hypothesis as it purports to support the ideal that banks that effectively and efficiently carry out their operations perform better financially as compared to those that do not. Banks with weak internal controls are prone to inefficiency, which promotes an enabling environment for fraud and mismanagement to thrive and this increases operational costs leading to poor financial performance. One of the main objectives of internal controls is to assure efficiency and effectiveness of operations.

\subsubsection{Agency theory}

It suggests that there is relationship between ownership structure and banks performance. It was formalized in a research by Jensen and Meckling (1976) and subsequently by Fama and Jensen (1983). The principal (owners of business) contracts an agent (managers of business) who is mandated to run a business on their behalf through delegated decision-making authority. According to Jensen and Meckling (1976), agency relationship is a contract which one or more person(s) (Principal(s)) engage another person (agent) to perform some service on behalf, which involves delegating some decision-making authority to the agent. Therefore, at the heart of the agency theory is the separation of ownership and control. Because both parties are utility maximizing, Principal-Agent conflict occurs which is termed as the agency problem. Other work related issues to this relationship include the moral hazard and adverse selection. Moral hazard arises when the agent is not doing exactly what he/she was appointed to do, and adverse selection stems from the agent not possessing the requisite knowledge about what should be done. However, solutions to agency problems have given rise to agency costs (monitoring expenses, bonding expenses and residual loss). Effective internal controls may address the agency problem and minimize agency costs through elimination of information asymmetry that may exist between the principal and the agent. Existing literature suggest that ownership structure and corporate governance influence performance. Banks with stringent and value based ownership have better profitability than mutual, or state owned banks. The principal-agent model suggests that managers are less likely to engage in strictly profit maximizing behavior in the absence of strict monitoring by shareholders (Agrawal \& Knoeber, 1996). In addition, internal controls are associated with increased earnings management. Earnings management is the agency problem that motivated the SOX legislation in response to earnings manipulation that leads to scandalous reporting as witnessed by Enron and WorldCom.

\subsubsection{Institutional theory}

It originated from works done by Meyer and Rowan (1977) and DiMaggio and Powell (1983). This theory proposes that organizations develop and design structures, processes and systems not primarily on rational economic cost-benefit analysis but because they are more or less required to incorporate new practices and procedures. According to Meyer and Rowan (1977), "Organizations are driven to incorporate the practices and procedures defined by prevailing rationalized concepts of organizational work and institutionalized in society. Organizations that do so increase their legitimacy and their survival prospects, independent of the immediate efficacy of the acquired practices and procedures." Organizational structures such as internal controls 
are symbols of conformity and social accountability. From the literature available, firms not only compete for clients and resources but also for institutional legitimacy and social fitness (DiMaggio and Powell, 1983). According to Arwinge (2013), Controls are adapted and designed in order to increase legitimacy and their survival prospects. This theory therefore is in tandem with the corporate governance and SOX requirements. The Sarbanes-Oxley Act of 2002 requires companies to report on the effectiveness of their Internal Controls over Financial Reporting as part of an overall effort to reduce fraud and restore integrity in the financial reporting process.

\subsection{Determinants of Financial Performance}

The financial performance in the banking sector is determined by both macroeconomic and bank specific factors as stipulated in most studies undertaken by scholars. The macroeconomic factors identified by scholars include; political instability, economic growth (GDP), inflation and Bank interest rate. On the other hand, the bank specific factors as stipulated by same scholars include; Bank ownership structure, bank size, and capital management efficiency and risk management capacity.

\subsubsection{Bank Specific Factors}

These are the internal factors specific to a bank. They are within the scope of the banks management to manipulate for the bank to perform financially. According to Dong (2011), the CAMEL framework is used to proxy bank specific factors by scholars. CAMEL is simply an acronym for; Capital adequacy, Asset quality, Management efficiency, Earnings ability and Liquidity. The CAMEL ratios measure overall performance of the banking system and determine the strengths and weaknesses of a bank in order to ensure safety and soundness of a bank.

Capital adequacy is the measure of financial strength of a bank, usually expressed as a ratio of its shareholders to total assets. Simply put, it is the owners fund available to support the bank's business and act as a buffer in case of adverse situations (Anthanasongoloa et al., 2005). It creates liquidity for the bank and reduces the chance of distress. Asset Quality involves Credit portfolio, fixed assets, Current assets and other investments. Loans are the major assets of commercial banks in Kenya from which they generate income. The quality of loan portfolio determines the profitability of banks (Ongore et al., 2013). Management efficiency's quantitative measure is complex to capture though is measured qualitatively by operational efficiency, subjective evaluation of management systems, organizational systems, w quality of staff and others. Earnings Ability refers to the profitability of the bank. Most commonly used ratios to proxy its measurement includes; ROA, ROE, NIM (Net Interest Margin), Net profit Margin (NPM), Return on Capital Employed (ROCE) and Earnings per Share (EPS). Liquidity refers to the ability of the bank to fulfill its financial obligations as they fall due (Dang, 2011).

\subsubsection{Macroeconomic Factors}

These external factors are not within the control of the management's manipulation but affect performance of the bank. These factors are not within the scope of this study and therefore are worth mentioning only. They include bank size, bank ownership structure, political instability, GDP growth rate, exchange rates, bank interest rates and many others as identified by scholars in their research work.

\subsection{Internal Control}

The COSO Internal Control Framework (2004) defines Internal Control as the "process effected by an entity's Board of Directors, Management and other personnel designed to provide reasonable assurance regarding the achievement of objectives related to operation, reporting and compliance". Internal control consists of controls designed to provide reasonable assurance that the company's financial statements are reliable and prepared in accordance with GAAP (ICFR). International Accounting Standards (IAS) categorizes internal controls as a plan of organization, segregation of duties, control of documents, safeguarding of assets, competence of staff, arithmetic and accounting controls, recording and record keeping, supervision, authorization and approvals, vocation and rotation of duties, cost feasibility, routine and automatic checks.

The Basel Committee on banking supervision issued a framework for evaluation of Internal Control Systems. It emphasized that sound Internal Controls are essential to the prudent operation of banks and promotes stability in the financial system. The Basel committee developed thirteen principles for banking supervisory authorities to apply in assessing bank's internal control systems. These principles were structured under five main areas namely; Management oversight and the control environment, Risk recognition and assessment, Information Communication and Monitoring activities \& Correcting deficiencies which have their basis on the COSO Framework.

Whittington and Pany (2001) note that the Control Environment sets the tone of the organization by influencing the control conscious of people. It is the foundation of all other components of internal control and 
provides discipline and structure. According to the COSO (2011) Internal Control - Integrated framework, the following factors describe the control environment fully; Management's philosophy and operating cycle, Management's assigning of authority and responsibility, Management's organization and development of its people, Intention and direction provided by the governing body and Principles of integrity, ethical values and competencies of the entity's personnel.

Risk Assessment involves identification and analysis of relevant risks to achievement of an entity's objectives that forms the basis for determining how the risk is mitigated. With reference to the COSO (2011) framework on internal control, Risk assessment is a systematic process for integrating professional judgment about probable adverse conditions and events, and assessing the likelihood of possible financial and nonfinancial losses resulting from their occurrence. According to Lannoye (1999), risk assessment highlights the importance of management, carefully identifying and evaluating factors that can hinder it from achieving its organizational objectives. Risk is inherent in every business entity whose source is either internal or external. Risk assessment must be a perpetual activity due to the dynamic nature of the business environment. It forms the basis of Enterprise Risk Management (ERM) in any organization that is instituted by the governing body. The definition and goals of ERM are provided by the COSO (2004) framework on internal control.

Control Activities are the policies and procedures that help ensure management's directives are carried out and the necessary actions taken to address risks to entity's objectives, COSO (2011). Control activities occur at all levels and functions of the entity. It involves approvals, authorizations, verifications, and reconciliations, review of operating performance, security of assets and segregation of duties.

Information and Communication involves identification, capturing and relaying important information to the organization effectively (COSO, 2011). Both upward and downward communication channels should be entrenched in the information and communication system. This enables the employees to have a clear understanding of the management's expectations and the management to have a clear understanding of the employees concerns. A communication system should relay reports that are reliable, timely and relevant from both internal and external sources for purposes of informed business decision making and external reporting.

Monitoring Activities involve a process that assesses the quality of the internal control system's performance over time. Monitoring assesses and seeks to mitigate the risks that internal controls within an organization will not provide reasonable assurance that the operational, reporting and legal/regulatory objectives are met, COSO (2011). It is a function of both Internal and External Auditing Departments. Monitoring should occur within the following framework; Internal Audit activities and Self- assessment of Internal Control Questionnaire.

\subsection{Financial Performance}

Performance refers to the ability to operate efficiently, profitably, survive, grow and react to the environmental opportunities and threats, Mawanda (2008). Return on Equity (ROE), Return on Assets (ROA) and Net Interest Margin (NIM) are often used to proxy the measurement of Financial Performance. This paper only discusses ROE. Other than profitability other indicators of financial performance in the banking sector are; liquidity, loan disbursement and customer netting. According to available literature, appropriate performance measures are those that enable organizations to direct their actions towards achieving their strategic objectives.

Accounting based performance measures have been done using three indicators; return on assets (ROA), return on equity (ROE) and return on sales (ROS). Each is determined by dividing net income by total assets, total common equity and total net sales, respectively. Return on Equity (ROE) is the amount of net income returned as a percentage of shareholders' equity. The return on equity ratio or ROE is a profitability ratio that measures the ability of a firm to generate profits from its shareholders' investments in the bank. ROE is also an indicator of how effective management is using equity financing to fund operations and grow the bank. Higher ratios are almost always better than lower ratios and shows how better the bank is at generating profits, but have to be compared to other companies' ratios in the industry. Many investors also choose to calculate the return on equity at the beginning of a period and the end of a period to see the change in return. This helps track a company's progress and ability to maintain a positive earnings trend. Averaging ROE over the past 5 to 10 years can give you a better idea of the historical growth.

\subsection{The Effect of Internal Control on Financial Performance.}

Muraleetharan (2011) found internal control system and financial performance were statistically significant in determining corporate goals. This is in tandem with the objective of this study. Internal controls promote efficiency, reduce risk of asset loss and help ensure the reliability of financial statements and compliance with the laws and regulations. Whittington and Pany (2001) talked about the comprehensiveness of internal controls in addressing the achievement of objectives in financial reporting, operations and compliance with laws and regulations. Doyle et al. (2005) found that the company level of control problems, which cannot be audited as easily, are associated with lower earnings quality, which explore links between disclosure of 
material weakness and fraud, earnings management or restatements. According to Magara (2013), effective internal controls are one of the mechanisms used to address the agency problems. Banks that have effective internal controls in place easily address the agency problems, minimize agency costs and mitigates against earnings management resulting to scandalous reporting that could lead to loss of resources. The agency problems discussed have a negative impact on Banks profitability.

\subsection{Review of related empirical studies}

Several scholars have carried out research in order to establish the relationship between internal control and financial performance. Ndamenenu (2011) carried out a research on internal control and its contributions to organizational efficiency and effectiveness: A case study of Ecobank Ghana Limited. The findings confirmed the assertion of the Treadway commission of the committee of sponsoring organizations (COSO), that it is management responsibility to set up the internal control system and that the internal auditor's role is to evaluate the effectiveness or otherwise of the system. The study concluded that the effectiveness and efficiency of the internal controls rest on the internal audit unit, and need to be institutionalized in any organization and within its branches.

Ayagre, et al. (2014) researched the effectiveness of Internal Control Systems of banks: The case of Ghanaian banks. This study evaluated the control environment and monitoring activities components of Internal Control Systems of Ghanaian Banks using COSO's principles and attributes of assessing the effectiveness of internal control systems. The study found out that, strong controls exist in the control environment and monitoring activities components of the internal control systems of banks in Ghana. The study recommended that boards of banks in Ghana should not be complacent about the findings but should work hard to ensure continuous ongoing and separate internal control monitoring to ascertain that controls really exist and are functioning properly.

Hayali, et al. (2014) studied the importance of internal control system in the banking sector: Evidence from Turkey. In this study, the importance of internal control system was expressed, also its impacts to the banking system analyzed. The research showed that the internal control activities of the banks are adapted to the international standards in Turkey and effective control procedures existed in the banking system. In addition, efficient internal control mechanisms have great impact on the strong and stable outlook of Turkish banking sector.

Bayyoud and Sayyad (2015) studied the impact of internal control and risk management on banks in Palestine. The investigation helped in identifying the impacts of new banking reformations and rules on the risk assessment, identification, and mitigation in banks. The findings showed that overall internal control and risk management systems in Palestine have positively affected the banks in terms of quantitative as well as qualitative performance.

Magara (2013) undertook to study the effect of internal controls on the Financial Performance of deposit taking Savings and Credit Cooperative Societies (SACCOs) in Kenya. The study used the control environment, risk assessment, control activities and monitoring to proxy internal control. They contributed positively to the financial performance of SACCOs in Kenya.

Nyakundi, et al. (2014) conducted a research on the Effect of internal control systems on financial performance of small and medium scale business enterprises in Kisumu City, Kenya. Based on the findings of the study, internal control systems significantly influence the financial performance of SMEs. The study also revealed that there were challenges in the implementation of internal controls especially considering that the internal audit function which is the backbone of internal controls is not adequately equipped by the technical manpower required, which clearly has affected their efficiency. Inadequate financial resources have also accelerated to their inefficiency, reflected by irregular audit activities as well as absence of regular reports. The study revealed shortcomings of business knowledge of entrepreneurs in ICSs. The study finally concluded that there is a significant positive relationship between internal control system and financial performance.

Ndiwa and Kwasira (2014) carried out a study guided by the Agency Theory to test empirically the effects of internal control on financial performance in tertiary institutions in Kenya. The study used a case study research design. The findings showed that the institution's Internal Audit Department inadequately staffed. It recommended The Internal Audit Department sufficiently staffed, and the recruitment process of the auditors should be free from the management influence.

Ireri and Wagoki (2014) carried out a study to establish the role of internal control system components in Kenyan public universities. The study found out that there were internal control mechanisms in the Kenyan universities but they were ineffective. The study recommended the strengthening of training and guidance in internal control systems to ensure that all employees not only were aware of controls but actively participate in their effectiveness. 


\subsection{Research Design}

\section{Research Methodology}

The researcher adopted a descriptive cross-sectional research design. According to Cooper \& Schindler, (2014), this kind of research design is adopted when the researcher is concerned in finding out the what for the research problem identified with definite issues to be responded to by the respondents. Purposive random sampling used defined the sample frame as the researcher aimed to use one respondent in senior management, middle level management or members of the internal control departments in each bank. These respondents exposed to a developed questionnaire with specific items to respond to, provided the data analyzed using descriptive statistical methods. The design was appropriate as it enabled the researcher determine the effect of ICs on financial performance of banks. The target population was based on a survey of the 43 Commercial Banks registered by the CBK as at $31^{\text {st }}$ December, 2014.

\subsection{Data Collection}

Both Primary and secondary sources of data were used to provide background information for this research. Primary data obtained was from the structured questionnaire given to the personnel in Senior \& Middle level management and the Internal Audit Department because they made decisions and implemented internal controls in the bank. Secondary data obtained from the CBK banks annual reports published financial statements on ROE over a period of five years from January 2010 to December 2014, depict an average that reflected a historical growth in the banking sector, executive summary, library journals and other relevant books and accounts of banks in Kenya.

The consistency and integrity of the data collected was checked. Verification of accuracy, uniformity and completeness was undertaken before final analysis was done in a thorough and scrupulous manner in order to enhance validity and reliability. According to Williman (2006), validity is the degree to which research findings (data collected) are true and reliability is the degree to which results of the research are repeatable. The reliability of the variables picked to represent financial performance and internal control was tested using the Cronbach's Alpha Coefficients from the pilot study that was carried out.

\subsection{Data Analysis.}

The whole process that starts immediately after data collection and ends at the point of interpretation and processing data is data analysis (Cooper \& Schindler, 2014). It helps to identify statistical patterns and relationships between variables used in the research. Data editing, data coding, and data entry were done carefully. In addition to this, qualitative analysis of the information collected from both primary and secondary sources that is more intuitive was based on judgmental consensus and expert information. A combination of both qualitative and quantitative methods was significant in the analysis and interpretation of the data collected. An F- test was used to establish the significance of the independent variables (control environment, risk assessment, control activities, information \& communication, and monitoring) against the dependent variable (ROE). The test of significance for the linear regression was conducted using probability value ( $\mathrm{P}$ Value) where the $\mathrm{P}$ - Value was $\mathrm{P}=0.000$ ( $\mathrm{P} \leq 0.05$ showing statistical significance).

\subsection{Analytical Model}

A regression analysis of the dependent and independent variables was used to predict the relationship between these variables. The linear regression model given in equatin (1) below was adopted for this study.

$$
\boldsymbol{Y}=\boldsymbol{\beta}_{0}+\beta_{1} X_{1}+\beta_{2} X_{2}+\beta_{3} X_{3}+\beta_{4} X_{4}+\beta_{5} X_{5}+\varepsilon
$$

Where;

$$
\left.\begin{array}{rl}
\mathrm{Y} & =\text { Financial Performance (from ROE; see Appendix II) } \\
\beta_{0} & =\text { Intercept (Constant) } \\
\beta_{1}-\beta_{5} & =\text { Measures of sensitivity of Variable } \mathrm{X} \text { to Variable } \mathrm{Y} \\
\mathrm{X}_{1} & =\text { Control Environment. } \\
\mathrm{X}_{2} & =\text { Risk Management } \\
\mathrm{X}_{3} & =\text { Information and Communication } \\
\mathrm{X}_{4} & =\text { Control Activities } \\
\mathrm{X}_{5} & =\text { Monitoring } \\
\varepsilon & =\text { Error term for the model }
\end{array}\right\} \text { from the Likert Scale in the questionnaire }
$$

The variables in the model above were operationalised as shown in Table 1.

The Analysis of Variance (ANOVA) predicted the effect of Internal Controls on Financial Performance had a regression value of 0.607 , while residual value of 0.324 . The study variables were statistically significant with $\mathrm{P}=0.000(\mathrm{P} \leq 0.050)$ and $\mathrm{F}$ - Test Tabulating $\mathrm{F}(5,35)=13.123$ as shown in Table 4.8 above. (Appendix 1 A). The model summery and regression of coefficients was performed in order to obtain the direction and relationship the coefficients give to the model parameters. (Appendix IB \& IC) 
The Effect of Internal Controls on the Financial Performance of Commercial Banks in Kenya

Table 1. Operationalization of Variables

\begin{tabular}{|c|c|c|}
\hline \multicolumn{2}{|l|}{$\operatorname{Variable}(s)$} & \multirow{2}{*}{ Measurement } \\
\hline $\begin{array}{l}\text { Dependent } \\
\text { (Financial } \\
\text { Performance) }\end{array}$ & ROE & \\
\hline \multirow[t]{5}{*}{$\begin{array}{l}\text { Independent } \\
\text { (Internal Control) }\end{array}$} & Control Environment & $\begin{array}{l}\text { Management philosophy \& operational style, Integrity \& ethical values, } \\
\text { A commitment to competence, Participation of board of directors or } \\
\text { audit committee, Organizational structure, Assignment of authority \& } \\
\text { responsibilities, Human resource policies and practices. }\end{array}$ \\
\hline & Risk Assessment & $\begin{array}{l}\text { Changes in operating environment, risk mitigation, Risk identification, } \\
\text { defined and clear objectives, Corporate restructuring, Level of risk } \\
\text { acceptable and maintained }\end{array}$ \\
\hline & Information and Communication & $\begin{array}{l}\text { Information needs, information control, management communication, } \\
\text { upstream communication with outside parties, information timing. }\end{array}$ \\
\hline & Control Activities & $\begin{array}{l}\text { Approvals, authorizations, verification, performance review, physical } \\
\text { control, Segregation of duties, }\end{array}$ \\
\hline & Monitoring & $\begin{array}{l}\text { On- going supervision and evaluation, internal audit, timely reviews, } \\
\text { self-assessment }\end{array}$ \\
\hline
\end{tabular}

\section{Data Analysis, Results And Discussion}

This section presents data analysis and interpretation on the Effect of Internal Controls on Financial Performance of Commercial Banks in Kenya.

\subsection{Data analysis and results}

The data obtained from the respondents to the questionnaire was analyzed using SPSS, v22. The results obtained are presented in form of tables showing means and standard deviations.

\subsubsection{Control Environment}

The respondents were required to rank their level of agreement of how effective their bank was with implementing the various indicators of control environment using the five point Likert scale. The ranking used was as follows: $1=$ Strongly Disagree; 2=Disagree; 3=Not Sure; 4=Agree; and 5=Strongly Agree.

Table 2 Control Environment

\begin{tabular}{|c|c|c|}
\hline Control environment factors & Mean & $\begin{array}{l}\text { Standard } \\
\text { Deviation }\end{array}$ \\
\hline Our Bank closely monitors the implementation of Internal Controls. & 4.32 & .820 \\
\hline $\begin{array}{l}\text { Our Bank provides feedback to the junior officers about the operation of the Internal } \\
\text { Controls. }\end{array}$ & 3.83 & 1.202 \\
\hline Our Bank has a code of conduct to guide behavior, activities and decision- making. & 4.27 & 1.073 \\
\hline Our Bank has an accounting and financial systems. & 4.44 & .867 \\
\hline Our bank has an objective, independent and active audit committee. & 4.27 & .949 \\
\hline The Board of Directors and its Committee are independent of Management. & 4.10 & 1.114 \\
\hline Ethical values are upheld in all the bank's decisions & 4.34 & .938 \\
\hline The Board, the Management and Employees are all committed to competence and integrity & 4.24 & 1.067 \\
\hline There is an atmosphere of mutual trust in our Bank & 3.98 & 1.012 \\
\hline Roles and responsibilities are clearly stated for employees & 4.20 & 1.123 \\
\hline Observations $(\mathrm{N})$ & & 1 \\
\hline
\end{tabular}

Source: Research data

From the findings in Table 2, factors measuring Control environment had positive Means of between 3.83 and 4.44 Standard Deviations of between 0.820 and 1.202 .

\subsubsection{Risk Assessment}

The respondents were required to rank their level of agreement with their banks effectiveness in risk assessment indicators using the five point Likert scale. From the research findings in Table 3, factors measuring Risk Assessment had positive Means of between 4.02 and 4.27 Standard Deviations of between 1.073 and 1.264.

Table 3. Risk Assessment

\begin{tabular}{|c|c|c|}
\hline Risk assessment factors & Mean & $\begin{array}{l}\text { Standard } \\
\text { Deviation }\end{array}$ \\
\hline Our Bank has defined appropriate objectives for the organization & 4.05 & 1.264 \\
\hline Our Bank identifies risks that affect achievement of the objectives in a timely manner & 4.02 & 1.084 \\
\hline Our Bank has a criteria for ascertainment of the risks that are most critical to the organization & 4.17 & 1.202 \\
\hline $\begin{array}{l}\text { Our Bank has in place mechanisms of mitigating critical risks that may arise during the course } \\
\text { doing business }\end{array}$ & 4.27 & 1.073 \\
\hline Observations $(\mathrm{N})$ & & \\
\hline
\end{tabular}




\subsubsection{Control Activities}

Respondents were required to rank their level of agreement to the extent to which their banks practiced control activities given in the questionnaire using the five point Likert scale ranging from strongly disagree to strongly agree.

Table 4. Control Activities

\begin{tabular}{|c|c|c|}
\hline Control Activities factors & Mean & Standard Deviation \\
\hline Our Bank has clear separation of roles. & 4.17 & 1.022 \\
\hline Every employee's work checks on the others. & 3.54 & 1.098 \\
\hline The staff is trained to implement the accounting and financial management systems. & 3.98 & 1.193 \\
\hline Corrective action is taken to address weakness & 4.15 & 1.014 \\
\hline Our Bank has a well-organized chart of accounts & 4.10 & .995 \\
\hline $\begin{array}{l}\text { It is impossible for one staff to have access to all valuable information without } \\
\text { consent from the senior staff. }\end{array}$ & 4.20 & 1.229 \\
\hline Controls are in place to check on incurring expenditure in excess of allocated funds. & 4.41 & .774 \\
\hline $\begin{array}{l}\text { Departments undertake budget reviews and variance from budgeted expenditure are } \\
\text { explained. }\end{array}$ & 4.22 & .962 \\
\hline Our security system identifies and safeguards the Bank's assets & 4.51 & .898 \\
\hline Our Bank's financial statements are regularly audited externally. & 4.46 & 951 \\
\hline Observations (N) & & 41 \\
\hline
\end{tabular}

Source: Research data

Table 4. shows that factors measuring Control Activities had positive Means of between 3.54 and 4.51 Standard Deviations of between 0.774 and 1.229 .

\subsubsection{Information and Communication}

The Respondents were required to rank the level of agreement to the extent to which they relate their banks Information and Communication strategy using a five point Likert scale ranging from strongly disagrees to strongly agree.

Table 5. Information and Communication

\begin{tabular}{|l|c|c|}
\hline Information and communication factors & Mean & Standard Deviation \\
\hline $\begin{array}{l}\text { Our Bank has identified individuals who are responsible for coordinating the various } \\
\text { activities within the bank }\end{array}$ & 4.00 & 1.095 \\
\hline $\begin{array}{l}\text { All the employees understand the concept and importance of internal control including the } \\
\text { division of responsibilities }\end{array}$ & 3.92 & .917 \\
\hline $\begin{array}{l}\text { Communication helps to evaluate how well the guidelines and policies of the bank are } \\
\text { working and are implemented. }\end{array}$ & 4.15 & 1.085 \\
\hline $\begin{array}{l}\text { The reporting system on the organizational structure spells out all the responsibilities of } \\
\text { each department in the bank. }\end{array}$ & 4.32 & 1.011 \\
\hline $\begin{array}{l}\text { Sufficient information is identified and communicated in a timely manner to enable people } \\
\text { perform their responsibilities }\end{array}$ & 4.27 & 1.073 \\
\hline Observations (N) & & 41 \\
\hline
\end{tabular}

Source: Research data

From the research findings in Table 5 above, it shows that factors measuring Information \& Communication had positive Means of between 3.92 and 4.32 Standard Deviations of between 0.917 and 1.095.

\subsubsection{Monitoring}

The respondents were required to rank the level of agreement to the extent to which their banks related to monitoring activities using a five point Likert scale ranging from strongly disagree to strongly agree.

Table 6. Monitoring

\begin{tabular}{|l|c|c|}
\hline Monitoring factors & Mean & Standard Deviation \\
\hline $\begin{array}{l}\text { Our Bank has assigned responsibilities for the timely reviews of the audit reports } \\
\text { and resolution of any non-compliance items noted in the audit reports }\end{array}$ & 4.24 & .943 \\
\hline $\begin{array}{l}\text { There are independent processes, checks and evaluation of control activities on an } \\
\text { ongoing basis }\end{array}$ & 4.12 & .872 \\
\hline Monitoring has helped in assessing the quality of performance of the bank over time & 4.29 & .901 \\
\hline $\begin{array}{l}\text { An internal review of implementation of the internal control system in departments } \\
\text { is conducted periodically to ascertain its effectiveness. }\end{array}$ & 4.32 & .756 \\
\hline $\begin{array}{l}\text { Management is closely monitoring the implementation of the internal control } \\
\text { system in our bank. }\end{array}$ & 4.44 & .867 \\
\hline Observations (N) & & 41 \\
\hline
\end{tabular}


Source: Research data

From the research findings in Table 6, factors measuring monitoring had positive means above four and standard deviations below one.

\subsection{Discussion}

Commercial Banks in Kenya effectively control the bank environment by; closely monitoring the implementation of internal controls, providing feedback to junior officers on internal controls, providing a code of code of conduct to guide employees, separating the accounting and financial departments, having an independent board of directors and its committee, upholding ethical values in all decisions, committing to competence and integrity, creating an environment of mutual trust within them and clearly stating roles and responsibilities of their employees.

Commercial Banks in Kenya undertake Risk Assessment. The findings revealed that Commercial banks have defined appropriate objectives, identify risks that can affect achievement of these goals in the stipulated time frame, have criteria in place for ascertaining risks critical to them, and have put in place mechanisms to mitigate these risks when they arise in the course of doing business.

The banking sector in Kenya control activities effectively by clear role separation, training employees on implementation of the accounting and financial management systems, addressing their weaknesses by corrective actions, having an organized chart of accounts, safeguarding access to valuable information and assets, controlling their expenditure, undertaking departmental budget reviews where variances have to be explained and regularly perform external audits. However, employs work checking on the others' work was not highly embraced.

An effective Information and communication system exists in the banking sector in Kenya. The research revealed that the system ensured timely, relevant and reliable information is identified, captured and relayed to relevant stakeholders and free communication flow has enabled employees to understand managements' expectations and management to understand employees concerns.

The banking sector has a monitoring process that assesses the quality and effectiveness of internal controls. This is done through periodic and ongoing reviews and closely supervising implementation. The regression analysis revealed that the model obtained has a significant positive relationship between Internal Controls and Financial Performance of Commercial Banks in Kenya. It implies that a unit increase (effective implementation) in any of the elements of Internal Controls will improve Financial Performance of Commercial Banks in Kenya. However, absence of internal control leads to loss (negative constant; -0.515, see Appendix IC). The model was found to be statistically significant and variation in the elements of internal controls affected the variation of financial performance by $60.2 \%$ as indicated by Adjusted $R^{2}=0.602$. (Appendix IA). This showed the model as a good predictor.

\section{Summary, Conclusion And Recommendations}

This section covers the summary of the research findings giving an overview of the study, conclusion that wraps up the study, policy recommendations and suggestions for further study and limitations that highlight the challenges encountered in the study.

\subsection{Summary of the Research Findings}

The research done established the Effect of Internal Controls on Financial Performance of Commercial Banks in Kenya. A Descriptive research design was employed with a population of 43 commercial banks used. Both primary and secondary data were used as sources of information. Primary data was collected through a questionnaire to 41 Commercial Banks in Kenya. The Questionnaire sort to collect relevant data to the study by obtaining respondent's level of education, years of experience in the banking sector, their view on the effect of internal controls on financial performance of commercial banks in Kenya and the effectiveness of the implementation of the five elements of internal controls (Control Environment, Risk Assessment, Control Activities, Information \& Communication and Monitoring) by ranking their level of agreement on a Likert scale.

Secondary data was collected from the Central Bank's banks supervision annual report publications. The values of ROE for the 43 Commercial Banks was collected from 2010 to 2014 in order to determine a historical average that was used in the research (Appendix II). The data collected was checked verified and cleaned for validity and reliability. Data analysis was done using the Statistical Package for Social Scientists (SPSS, v.22) for linear regression and descriptive statistics such as mean and standard deviation. Results obtained were presented using charts, graphs and tables and inferences made and discussed as given in this study. 


\subsection{Conclusion}

The study findings revealed that commercial Banks that effectively implemented elements of internal controls had relatively better financial performance. The large peer banks had relatively better financial performance than the medium and smaller peer banks. From the regression analysis there was a significant positive relationship between Internal Controls and Financial Performance of Commercial Banks in Kenya, and absence of internal controls results in negative financial performance. In a nutshell the banking sector in Kenya enjoys a strong financial performance partly as a result of implementing and maintaining effective internal controls. The existence of effective internal controls may be attributed to the highly regulated and structured environment in the banking sector.

\subsection{Recommendation for Policy Development}

The study recommended that the banks should effectively implement and maintain internal controls due to the nature of the riskiness of the banking sector and its impact on the economic growth of the Country. The banks must have an independent Board of Directors and its committee as a Corporate Governance regulatory requirement. Besides this, an independent audit department that is well trained and staffed should be set in all the branches of the banks to facilitate effective implementation of internal controls.

Banks should have in place an information system that facilitates relaying of timely, relevant and reliable information to stakeholders and free upward and downward flow of information between management and employees. Ethical values should be upheld in decision-making, integrity and competence enhanced. Above all the management should ensure an atmosphere of mutual trust exist within their banks. Banks should design and organize for constant seminars and workshops to train its management and employees in finance, accounting, and internal audit departments pertaining Internal Controls, policies and procedures in order to enhance their professional skills and practices.

The Kenya Bankers Association should monitor and supervise Commercial Banks in Kenya to ensure financial reporting, legal and regulatory requirements are met by the banks and transparent periodic reporting to stakeholders on Corporate Governance, Risk Management and Internal Controls is undertaken.

\subsection{Limitations of the Study}

The study was limited only to the 43 registered commercial banks operating in Kenya as at $31^{\text {st }}$ December, 2014 where each bank had a single questionnaire filled. The Internal Control framework adopted considered only the COSO framework assuming that there were no other internal control frameworks contributing to financial performance. The study only focused on ROE as the measure of financial performance. It did not explore how other measures of financial performance such as NIM, ROA and ROS in order to establish how internal controls relate to other measures of financial performance. Therefore, research findings are inconclusive on the effect of internal controls on financial performance of commercial banks.

\section{Acknowledgements}

I wish to extend my gratitude to Herick Ondigo Ochieng and Justus Ochieng for their professional advice and guidance throughout the research project. My sincere thanks goes to the staff of the 41 banks who were respondents to the research questionnaire for their invaluable contribution that enabled me collect the data for this research.

\section{Notes about the Author}

Mr Asiligwa, G. Rennox is a Student of Finance and and Accounting, having graduated at the University of Nairobi, Kenya with a Master of Science (Finance) in 2015. Besides, he has a B.Ed (Science) from Kenyatta University, Kenya and has a long teaching background in Mathematics and Physics.

\section{Refferences}

[1]. Flamini, V., McDonald, C., \& Schumacher, L. (2009). The Determinants of Commercial Bank Profitability in Sub-Saharan Africa

[2]. COSO. (1992/2004). Internal Control- Intergrated Framework, Committee of Sponsoring Orgarnisations of the Treadway Commission. New York: Coopers and Librand.

[3]. COSO. (2011). Internal Control- Intergrated Framework, Committee of Sponsoring Orgarnisations of the Treadway Commission. New York: PWC.

[4]. Surbanes- Oxley Act. (2002). One Hundredth Congress of the USA at the 2nd Session 302 and 404. Washington.

[5]. Basel. (1999). Pinciples for the Management of Credit Risk . Basel Committee on Banking Supervision. Retrieved 08 05, 2015, from www.bis.org/publ/bcbs33.pdf

[6]. Basle Committee on banking supervision. (1998). Framework for Evaluation of Internal Control Systems. Retrieved 08 05, 2015, from www.bis.org/publ/bcbs33.pdf

[7]. Mawanda, S. (2008). Effects of Internal Control System on Financial Performance in Uganda's Institution of Higher Learning. Dissertation for awrd of MBA in Uganda Martyrs University.

[8]. Jensen, M., \& Meckling, W. (1976). Theory of The Firm:Managerial Behaviour, Agency Costs, and Capital structure. Journal of Financial Economics, 3, 305-360. 
[9]. Jensen, K. L., \& Jeff, P. J. (2003). Management Trade-offs of Internal Control and External Auditor Expertise. Auditing: A Journal of Practise \& Theory, 22(2), 99-119.

[10]. Abdel-Khalik, A. (1993). Why Do Private Companies Demand Auditing? The Case For Loss Control. Journal of Accounting and Auditing , Auditing and Finance, 8, 31-52.

[11]. Ejoh, N., \& Ejom, P. (2014). Impact of Internal Control Activities on Financial Performance of Tertiary Institutions in Nigeria. Journal of Economics and Sustainable Development, 5(16), 133-143.

[12]. Ayagre, P., Appiah-Gyamerah, \& Joseph, N. (2014). The Effectiveness of Internal Control Systems of Banks. The Case of Ghanain Banks. International Journal of Accounting and Financial Reporting, 4(2), 377-389.

[13]. Bayyoud, M., \& sayyad, A. (2015). the Impact of Internal Control and Risk Management on Banks in Palestine. International Journal of Economics, Finance and Management Science, 3(3), 156 - 161.

[14]. Islam, A., Saddiq, M. H., Hossain, F., \& Karim, L. (n.d.). Performance Evaluation of the Banking Sector in Bangladesh: A Comparative Analysis. Business Economic Rresearch, Vol. 4(No.1).

[15]. Magara, N. (2013). Effect of Internal Control on Deposit Taking Savings and credit Cooperative Societies. Research Project for the Award of MSc, University of Nairobi.

[16]. Nyakundi, D. O. (2014). Effect of internal control systems on financial performance of small and medium scale business enterprises in Kisumu City. International Journal of Social Sciences and Entrepreneurship, vol 4(No 1), 719-734.

[17]. Kamau, C. (2013). Effect of Internal Control on Financial Performance of Manufacturing Firms in Kenya. Research Project for award of MSc. , University of Nairobi.

[18]. Onuonga, S. M. (2014). The Analysis of Profitability of Kenya`s Top Six Commercial Banks: Internal Factor Analysis. American International Journal of Social Science, 3(5).

[19]. Ongore, V. O., \& Kusa, G. B. (2013). Determinants of Financial Performance of Commercial Banks in Kenya. International Journal of Economics and Financial Issues, 3(1), 237- 252.

[20]. Olweny, T., \& Shipho, T. M. (2011). Effects of Banking sectoral factors on the Profitability of commercial Banks in Kenya Economics and Finance Review Vol. 1(5) pp. 01 - 30, July, 2011, 1(5), 01 - 30. Retrieved 8 2015, from http://wwww.businessjournalz.org/efr

[21]. Demsetz, H. (1973,1974). Industry Structure, Market Rivalry and Public Policy. Journal of Law and Economics(No. 16), 1-9.

[22]. Sam Peltzman (1977). The Gains and Losses from Industrial Concentration. Journal of Law and Economics. 20(2), 229-264

[23]. Berger, Allen. (1995). Relationship between Capital and Earnings in Banking.Journal of Money, Credit and banking, 27(2), 432-56.

[24]. Park, K., \& Weber, W. (2006). Profitability of Korean Banks: Test of Market Power ersus Efficiency Structure. Journal of Economics and Business, vol. 58(3), 222 - 239.

[25]. Mensi, S., \& Zouari, A. (2010). Efficient Structure Versus Market Power: Theoretical and Empirical Evidences. International Journal of Economics and Finance, 2(4).

[26]. Chortareas, G., Garza-Garcia, G., \& Claudia, G. (2009). Banking Sector Performance in latin America: Market Power Versus Efficiency. Retrieved from on 8-6, 2015 from www.bis.org

[27]. Eugene, F. Fama \& Michael, C. Jensen (1983) Separation of Ownership and Control. Journal of Law and Economics, 26(2), 301325 .

[28]. Agrawal, A. \& Charles, R. Knoeber (1996). Firm Performance and Mechanism to Control Agency Problems between Managers and Shareholders. Journal of Financial and Quantitative Analysis, 31(3), 377-397.

[29]. John, W. Meyer \& Brian Rowan (1977). Institutionalized Organizations: Formal Structure as a Myth and Ceremony. American Journal of Sociology, 83(2), 340-364.

[30]. Paul, J. DiMaggio \& Walter, W. Powell (1983). The Iron Cage Revisited: Institutional Isomorphism and Collective Rationality in organizational Fields. American Sociological Review, 48(2), 147-160

[31]. Arwinge, Olof (2013) Internal Control: A Study of Concept and Themes. Springer- Verlag Berlin Heldelberg, pp31.

[32]. Dang, Uyen. (2011). The CAMEL Rating System in Banking Supervision: A Case Study of Arcada University of Applied Sciences.

[33]. Athansasoglou, P., Brissimis, S., \& Delis, M. (2006). Bank-Specific, Industry-Specific and Macroeconomic Determinants of Bank Profitability. Journal of International Financial Markets, Institutions and Money, 121-136. Retrieved 8 6, 2015, from http://ssrn.com/abstract=1106825

[34]. Centre for Audit Quality. (2004). Guide to Internal Control over Financial Reporting(ICFR). Washington, DC.

[35]. Whittington, O. R., \& Panny, K. (2001). Principles of Auditingand Assurance Services. NewYork: Irwin/ MacGraw-Hill.

[36]. COSO (2004). Internal Control- Intergrated Framework, Committee of Sponsoring Orgarnisations of the Treadway Commission. New York: PWC

[37]. Lannoye, M. (1999). Evaluation of Internal Controls. Michigan: McGraw - Hill. Retrieved 12 10, 2015, from www.michigan.gov/documents/gfmaster 26775 7.pdf

[38]. Muraleetharan, P. (2011). Internal control and Impact of Financial Performance of the organizations "special reference public and private organizations in Jaffna district" University of Jaffna.

[39]. Doyle, J., W.Ge, \& S.McVay (2005). Weakness in Internal Control Over Financial Reportingand the Implications for EarningsQuality. Working Paper.

[40]. Ndamemenu, D. K. (2014). Internal Control and its Contribution to Organizational Efficiency and Effectiveness: A Case Study of Ecobank Ghana Limited. Retrieved from http://ir.knust.ed.gh/handle/123456789/4210

[41]. Hayali, A., Dinc, Y., Sarih, S., Dizman, A. S., \& G., A. (2012). Importance of Internal Control Systems in the Banking Sector: Evidence from Turkey. Thesis.

[42]. Ireri, S. K., \& Juma, W. (2014). Assessing the role of Internal Control System Components in Kenya. International Journal of Accounting and Financial Management Research, 4(3), 17-28.

[43]. Williman, N. (2006). Social Research Methods. (1St, Ed.) London.Thousand Oaks. NewDelhi: Sage Publications.

[44]. Cooper, R. D., \& Schindler, S. P. (2014). Business Research Methods (12 ed.). New York, 1221 avenue, USA: McGraw- Hill/Irwin.

[45]. Central Bank of Kenya. (2010-2014). Bank Supervision Annual Report. Nairobi: CBK. 


\section{APPENDIX}

Appendix I: Regression Analysis

Appendix IA: Model Summery

\begin{tabular}{|l|r|r|r|r|}
\hline Model & $R$ & \multicolumn{1}{|c|}{$R$ Square } & Adjusted $R$ Square & Std. Error of the Estimate \\
\hline 1 & $.808^{\mathrm{a}}$ & .652 & .602 & .09620 \\
\hline
\end{tabular}

Source: Research Data

Appendix IB: Analysis of Variance

\begin{tabular}{|ll|r|r|r|r|r|}
\hline Model & & Sum of Squares & df & Mean Square & F & Sig. \\
\hline 1 & Regression & .607 & 5 & .121 & 13.123 & \\
& Residual & .324 & 35 & $.000^{\mathrm{b}}$ & & \\
& Total & .931 & 40 & & & \\
\hline
\end{tabular}

Source: Research Data

Appendix IC: Test for coefficients

\begin{tabular}{|c|c|c|c|c|c|c|}
\hline \multirow{2}{*}{\multicolumn{2}{|c|}{ Model }} & \multicolumn{2}{|c|}{ Unstandardized Coefficients } & \multirow{2}{*}{$\begin{array}{c}\text { Standardized } \\
\text { Coefficients }\end{array}$} & \multirow[b]{2}{*}{$t$} & \multirow[b]{2}{*}{ Sig. } \\
\hline & & $\mathrm{B}$ & Std. Error & & & \\
\hline \multirow[t]{6}{*}{1} & (Constant) & -.515 & .103 & & -5.005 & .000 \\
\hline & Control Environment & .008 & .037 & .039 & .208 & .837 \\
\hline & Risk Assessment & .043 & .030 & .289 & 1.434 & .160 \\
\hline & Control Activities & .062 & .046 & .276 & 1.332 & .191 \\
\hline & $\begin{array}{l}\text { Information and } \\
\text { Communication }\end{array}$ & .014 & .035 & .081 & .393 & .697 \\
\hline & Monitoring & .043 & .047 & .203 & .931 & .358 \\
\hline
\end{tabular}

Source: Research Data

Appendix II: ROE of Commercial Banks in Kenya (\%)

\begin{tabular}{|c|c|c|c|c|c|c|}
\hline BANK/YEAR & 2010 & 2011 & 2012 & 2013 & 2014 & AVERAGE \\
\hline Bank of Africa $(\mathrm{K}) \mathrm{Ltd}$ & 16.45 & 11.87 & 12.7 & 15.7 & 2.6 & 11.86 \\
\hline African Banking Corporation Ltd & 29.46 & 30.28 & 26.4 & 23.6 & 12.1 & 24.37 \\
\hline Bank of Baroda & 38.52 & 33.96 & 28.9 & 33.1 & 27.3 & 32.36 \\
\hline Bank of India & 35.94 & 28.87 & 14.9 & 24.6 & 21.1 & 25.08 \\
\hline Barclays Bank of Kenya Ltd & 34.25 & 41.11 & 44.0 & 36.8 & 32.3 & 37.69 \\
\hline CfC Stanbic Bank (K) Ltd & 20.96 & 30.82 & 26.0 & 31.1 & 27.7 & 27.32 \\
\hline Chase Bank Ltd & 31.20 & 28.62 & 25.8 & 30.1 & 29.8 & 29.10 \\
\hline Citibank N.A. Kenya & 22.34 & 31.77 & 41.7 & 31.2 & 22.6 & 29.92 \\
\hline Commercial Bank of Africa Ltd & 36.06 & 30.04 & 34.3 & 32.5 & 25.3 & 31.64 \\
\hline Consolidated Bank of Kenya Ltd & 17.45 & 17.18 & 11.2 & -11.5 & -17.5 & 3.37 \\
\hline Co - operative Bank of Kenya Ltd & 27.52 & 29.41 & 33.1 & 30.0 & 29.5 & 29.91 \\
\hline Credit Bank Ltd & 3.55 & 5.35 & 6.9 & 5.9 & -7.8 & 2.78 \\
\hline Development Bank of Kenya Ltd & 15.85 & 10.08 & 6.3 & 15.0 & 11.5 & 11.75 \\
\hline Diamond Trust Bank (K) Ltd & 35.64 & 31.34 & 31.4 & 30.0 & 24.5 & 30.58 \\
\hline Dubai Bank Ltd & 0.56 & 2.92 & -3.3 & 1.5 & 0.7 & 0.48 \\
\hline Ecobank Kenya Ltd & -3.70 & 7.03 & -76.7 & -36.3 & -6.4 & -23.21 \\
\hline Equatorial Commercial Bank Ltd & 43.76 & 5.91 & -90.8 & 11.1 & -39.9 & -13.99 \\
\hline Equity Bank Ltd. & 32.90 & 34.53 & 37.6 & 36.0 & 49.4 & 38.09 \\
\hline Family Bank Ltd & 16.01 & 15.72 & 17.4 & 29.5 & 24.7 & 20.67 \\
\hline Fidelity Commercial Bank Ltd & 46.99 & 29.64 & 8.6 & 22.4 & 17.3 & 24.99 \\
\hline Guaranty Trust Bank & 11.32 & 20.22 & 13.9 & 6.8 & 9.6 & 12.37 \\
\hline First Community Bank Ltd & -28.24 & 13.34 & 27.3 & 16.6 & 6.7 & 7.14 \\
\hline Giro Commercial Bank & 47.35 & 20.90 & 11.7 & 18.4 & 19.5 & 23.57 \\
\hline Guardian Bank Ltd & 11.77 & 15.94 & 18.3 & 25.7 & 21.5 & 18.64 \\
\hline Gulf African Bank Ltd & 43.84 & 11.78 & 23.9 & 16.1 & 19.5 & 23.02 \\
\hline Habib Bank Ltd & 26.24 & 19.23 & 33.8 & 30.0 & 27.4 & 27.33 \\
\hline
\end{tabular}


The Effect of Internal Controls on the Financial Performance of Commercial Banks in Kenya

\begin{tabular}{|c|c|c|c|c|c|c|c|}
\hline 27 & Habib Bank A.G. Zurich & 22.15 & 19.82 & 26.9 & 25.7 & 28.6 & 24.63 \\
\hline 28 & I\&M Bank Ltd & 23.15 & 32.17 & 28.5 & 29.5 & 35.5 & 29.76 \\
\hline 29 & Imperial Bank Ltd & 40.31 & 44.28 & 42.0 & 43.6 & 36.0 & 41.24 \\
\hline 30 & Jamii Bora Bank Ltd & -8.19 & -2.43 & 2.5 & 14.0 & 3.1 & 1.80 \\
\hline 31 & Kenya Commercial Bank Ltd & 28.23 & 31.18 & 29.8 & 28.4 & 31.5 & 29.82 \\
\hline 32 & K - Rep Bank Ltd & 9.55 & 19.23 & 20.1 & 29.8 & 30.0 & 21.74 \\
\hline 33 & Middle East Bank (K) Ltd & 20.01 & 8.40 & 4.2 & 6.9 & 6.2 & 9.14 \\
\hline 34 & National Bank of Kenya Ltd & 27.17 & 23.37 & 11.0 & 15.5 & 19.2 & 19.25 \\
\hline 35 & NIC Bank Ltd & 30.60 & 33.95 & 28.6 & 29.6 & 26.9 & 29.93 \\
\hline 36 & Oriental Commercial Bank Ltd & 16.06 & 14.93 & 8.2 & 11.7 & 5.3 & 11.24 \\
\hline 37 & Paramount Universal Bank Ltd & 35.78 & 11.00 & 7.9 & 8.1 & 9.9 & 14.54 \\
\hline 38 & Prime Bank Ltd & 19.74 & 28.88 & 27.8 & 32.5 & 29.7 & 27.72 \\
\hline 39 & Standard Chartered Bank (K) Ltd & 37.94 & 40.11 & 37.6 & 37.0 & 35.4 & 37.61 \\
\hline 40 & Trans - National Bank Ltd & 10.29 & 16.92 & 17.6 & 12.0 & 10.0 & 13.36 \\
\hline 41 & UBA Kenya Ltd & -15.54 & -25.19 & -32.6 & -26.2 & -29.1 & -25.73 \\
\hline 42 & Victoria Commercial Bank Ltd & 28.19 & 26.32 & 24.1 & 23.2 & 22.1 & 24.78 \\
\hline 43 & Charter House Bank Ltd & - & - & - & - & - & - \\
\hline
\end{tabular}

Source: Central Bank of Kenya,(2014)Bank Supervision Annual Report. CBK, Nairobi. 